\begin{tabular}{|l|l|}
\hline $\begin{array}{l}\text { 2. To: (Receiving Organization) } \\
\text { Distribution }\end{array}$ & $\begin{array}{l}\text { 3. From: (Originating organization) } \\
\text { Spent Nuclear Fuel Evaluations }\end{array}$ \\
\hline 5. Proj./Prog./Dept./Div.: & 6. Cog. Engr.: \\
Spent Nuclear Fuels Project & B. J. Makenas \\
\hline
\end{tabular}

8. Originator Remarks:

$N / A$

11. Receiver Remarks:
4. Retated EDT No.:

N/A

7. Purchase Order No.:

N/A

9. Equip./Component No.:

N/A

10. Systen/Bldg./Facility: $N / A$

12. Major Assm. Dwg. No.: $N / A$

13. Permit/Permit Application Ho.:

N/A

14. Required Response Date:

$$
N / A
$$

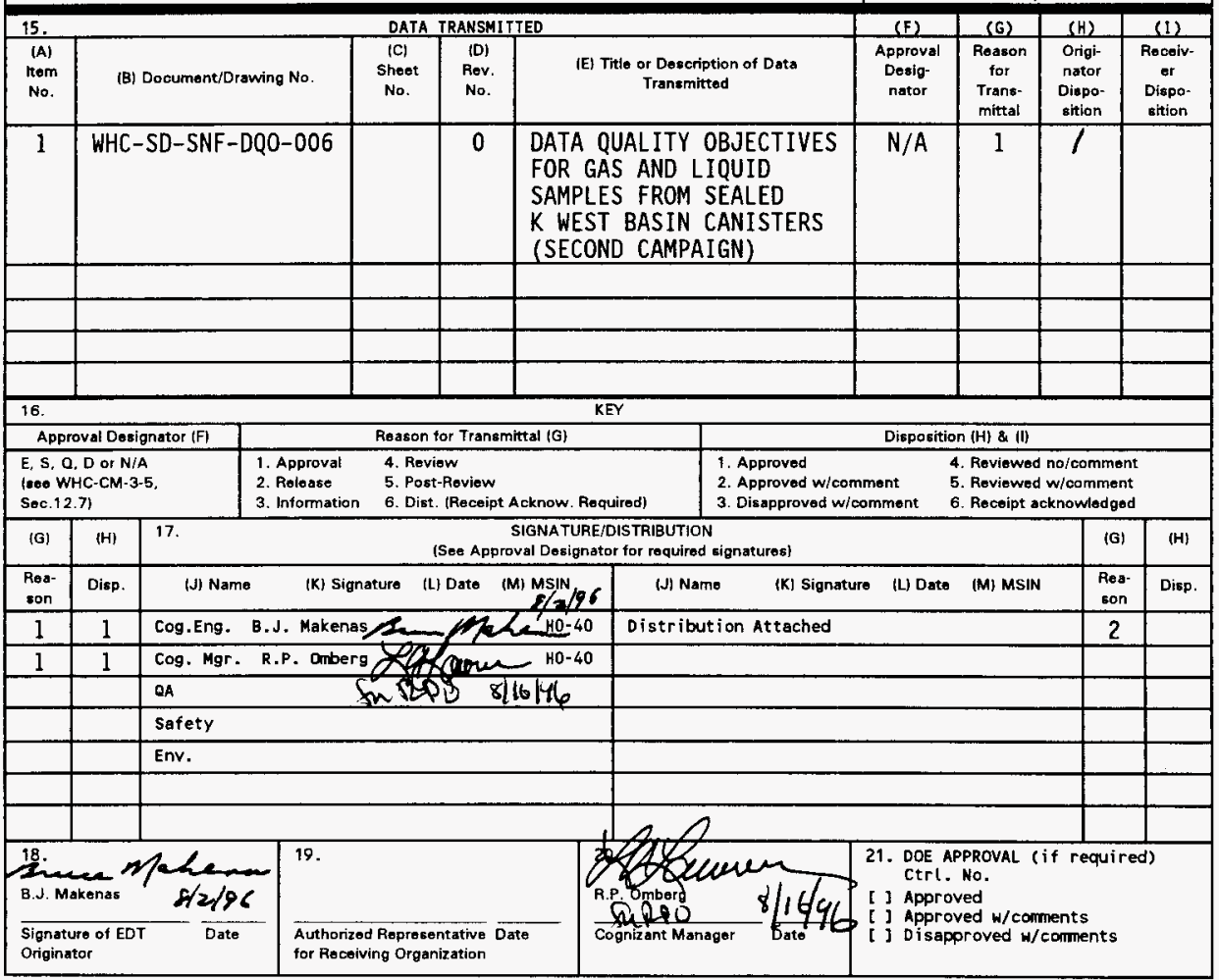




\section{DATA QUALITY OBJECTIVES FOR GAS AND LIQUID SAMPLES FROM SEALED $K$ WEST BASIN CANISTERS (SECOND CAMPAIGN)}

B. J. Makenas, D. J. Trimble and D. W. Bergmann Westinghouse Hanford Company, Richland, WA 99352 U.S. Department of Energy Contract DE-ACO6-87RL10930

EDT/ECN: 615490

Org Code: $8 M 710$

B\&R Code: EW 135040
UC: 2070

Charge Code: LBO22

Total Pages: 40

Key Words: DQ0, 105-K West, Canister Sampling, SNFP, Gas Samples, Liquid Samples, Characterization.

Abstract: Data Quality Objectives (DQ0s) for gas and liquid sampling from the sealed canisters in $K$ West Basin have been developed and are presented in this document. This sampling campaign supports the selection of canisters to provide fuel for hotcell examinations and provides an assessment of gas/liquid chemistry for comparison to the results of fuel element hotcell examinations. It also provides information applicable to water cleanup and air permits for the fuel handling associated with moving fuel to dry storage.

TRADEMARK DISCLAIMER. Reference herein to any specific commercial product, process, or service by trade name, trademark, manufacturer, or otherwise, does not necessarily constitute or imply its endorsement, recommendation, or favoring by the United States Government or any agency thereof or its contractors or subcontractors.

Printed in the United States of America. To obtain copies of this document, contact: HHC/BCs Document Control Services, P.0. Box 1970, Mailstop H6-08, Richland wa 99352, Phone (509) 372-2420; Fax (509) 376-4989.
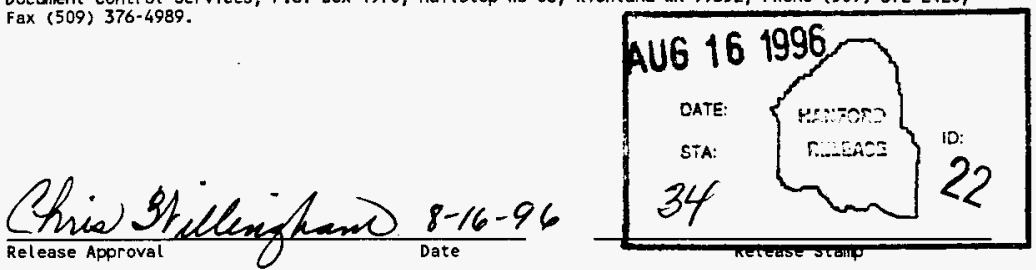
WHC-SD-SNF-DQO-006, Rev. 0

DATA QUALITY OBJECTIVES FOR GAS AND LIQUID SAMPLES FROM SEALED $K$ WEST BASIN CANISTERS (SECOND CAMPAIGN)

B. J. Makenas, D. J. Trimble and D. W. Bergmann Westinghouse Hanford Company

July 1996 
Document Title: DATA QUALITY OBJECTIVES FOR GAS AND LIQUID SAMPLES FROM SEALED $K$ WEST BASIN CANISTERS (SECOND CAMPAIGN)

Prepared by:

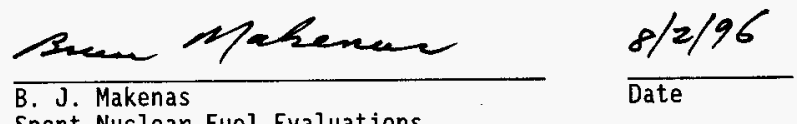

Prepared by:

Spent Nuclear Fuel Evaluations

Approved by:

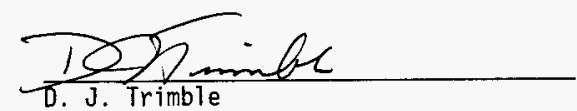

Spent Nuclear Fuel Evaluations

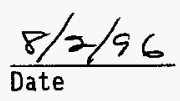

Approved by:
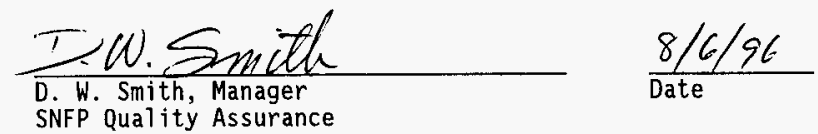

Approved by:

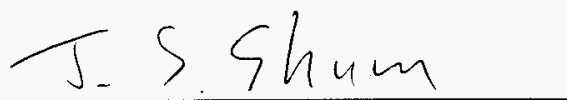

J. Shuen

U.S. Department of Energy

Richland office

$\frac{8 / 14 / 96}{\text { Date }}$ 
WHC-SD-SNF-DQ0-006, Rev. 0

This page intentionally left blank. 


\section{EXECUTIVE SUMMARY}

Data Quality objectives (DQOS) for gas and liquid sampling from the sealed canisters in $K$ West Basin have been developed and are presented in this document. This sampling campaign supports the selection of canisters to provide fuel for hot cell examinations and provides an assessment of gas/liquid chemistry for comparison to the results of fuel element and sludge hot cell examinations. It also provides information applicable to water cleanup and air permits for the fuel handing associated with moving fuel to dry storage.

It is proposed here that samples of gas and water be analyzed for constituents such as cesium, strontium, inhibitor remnants fission gas (krypton), and hydrogen. Several of these are markers for corrosion of uranium in a water environment. These data will allow an assessment of the risks involved when particular canisters are opened to retrieve fuel. This sampling campaign will also ensure that canisters with some failed fuel elements are included in the population that is opened for retrieval of fuel for hot cell examinations. Additionally, valuable correlations between the macroscopic visible condition of fuel, hot cell examinations, and the gases generated in canisters will be possible. The analysis of other chemical species in the gas and liquid will allow assessments of the performance of the previously added corrosion inhibitor and possibly assessments of radiolysis.

Sampling of canisters will be performed with equipment that opens the valves in the canister 1 id and draws a $20 \mathrm{ml}$ sample of either gas or water. This work will be performed in one of the pits associated with the $k$ West Basin. 
WHC-SD-SNF-DQ0-006, Rev. 0

This page intentionally left blank. 
WHC-SD-SNF-DQ0-006, Rev. 0

\section{CONTENTS}

1.0 INTRODUCTION . . . . . . . . . . . . . . . . . . 7

2.0 State the PROBLEM AND REVIEW PREVIOUS DATA . . . . . . . . 9

3.0 IDENTIFY THE DECISIONS OR DECISION PATHS . . . . . . . . 13

4.0 THE DATA TO BE ACQUIRED AND TECHNIQUES TO BE UTILIZED . . . . . 15

5.0 DEFINE THE BOUNDARIES OF THE SECOND GAS LIQUID SAMPLING CAMPAIGN . . 19

6.0 DECISION LOGIC . . . . . . . . . . . . . . . 23

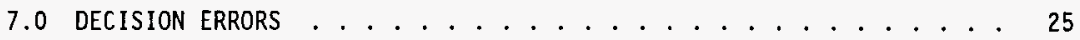

8.0 DECISION OPTIMIZATION ................. 27

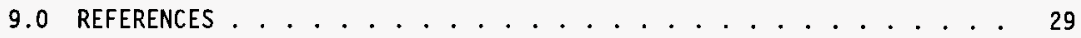

APPENDIX A SUMMARY OF PREVIOUS DATA FROM GAS AND LIQUID

SAMPLING OF $K$ WEST CANISTERS ........... 31

APPENDIX B LIST OF STAKEHOLDERS . . . . . . . . . . . . . . 35 
WHC-SD-SNF-DQ0-006, Rev. 0

This page intentionally left blank. 
WHC-SD-SNF-DQO-006, Rev. 0

\section{DATA QUALITY OBJECTIVES FOR GAS AND LIQUID SAMPLES FROM SEALED K WEST BASIN CANISTERS (SECOND CAMPAIGN)}

\subsection{INTRODUCTION}

This document describes the Data Quality Objectives (DQOs) for the effort to obtain samples of gas and water from the sealed canisters in the Hanford $K$ West Basin. As such, it follows the general guidelines stated in the Spent Nuclear Fuel (SNF) DQO strategy document (Lawrence 1994). It is an attempt to unequivocally state the reasons this sampling effort is being undertaken, to del ineate the boundaries of the effort, and to document the fact that considerable input has been gathered during the process of DQO formation. Listed below are each of the DQO steps and some detail on how each of the steps has been or will be addressed. The input given below was obtained though a series of meetings with small groups of participants. It was recognized at the outset that the set of stakeholders was large and encompasses viewpoints that are widely varied. The proposed experimental efforts in the arena of gas/liquid sampling discussed in this report hold promise to be of value as a guide to future efforts that sample sludge and fuel specimens and to those efforts concerned with longer term processing and storage of the $\mathrm{N}$ Reactor fuel, i.e., the Path Forward (see Fulton 1994). 
WHC-SD-SNF-DQO-006, Rev. 0

This page intentionally left blank. 
WHC-SD-SNF-DQO-006, Rev. 0

\subsection{STATE THE PROBLEM AND REVIEW PREVIOUS DATA}

Over three thousand canisters reside in the water-filled Hanford $\mathrm{K}$ West Basin. A canister may contain up to $14 \mathrm{~N}$ Reactor fuel assembijes (14 inner elements and 14 outer elements consisting primarily of metallic uranium with zirconium alloy cladding) distributed between two stainless steel or aluminum barrels. The canisters were initially filled in the 1980's with fuel, water, corrosion inhibitor and a nitrogen cover gas. The fuel elements are believed to be in assorted conditions which span the gamut from pristine to badly damaged. Canisters also contain sludge which is a direct result of the corrosion of fuel. The canisters may be of Mark I or Mark II design and all were initially sealed with metal lids so that the condition of the contents is not readily observed. The contents of the canisters was not inspected for more than a decade (1983 to 1995). Historical data (circa 1983), similar to that being proposed in this $\mathrm{DQO}$, are summarized in references

(Emory 1994; Mollarus 1995). As pointed out in a review article (Weber 1994), some corrosion of exposed uranium fuel is almost certainly occurring. The extent of this corrosion is not known but when it occurs, fission products and hydrogen are released into the canister. These species are available for release to the surrounding environment if the canisters are opened during a future processing/shipping scheme or if the canisters are disturbed in a way which affects the gas traps or lids associated with the canisters. In fact some canisters are known to have leaking seals and the gas traps are known to have various proportions of gas and water. Some radioactive species were indeed found in canister water during the 1983 campaign but it is not at all clear that these data can be extrapolated to the present or into the future.

A more recent campaign of gas/liquid sampling took place in 1995 and included 10 SS MK II canisters with MK IV fuel from a single fuel key group. Up to $0.5 \mathrm{Ci}$ per barrel of cesium-137 was found in the canister water and the nitrogen cover gas was found to be displaced by hydrogen and limited amounts of krypton gas. Detailed results from this campaign are given in (Trimble 1996a, 1996b) and are summarized in Appendix A. DQ0s for that campaign are in reference (Makenas 1995a) and laboratory procedures utilized are specified in reference (Harris 1995).

The three principal questions to be addressed by the upcoming gas/liquid sampling campaign are discussed below. Table l summarizes the various parts of the SNF project which will utilize the fuel, sludge and gas/liquid data along with need dates.

Limited gas/liquid sampling will be used as a tool to screen canisters which might be candidates to supply fuel elements and sludge for characterization hot cell examinations. Such screening is important from safety and operational points of view since the contents of an opened canister will at least temporarily raise the concentration of radioactive species in the basin water. From a characterization point of view gas/liquid sampling increases the certainty that canisters with a significant volume of siudge and the desired amount of corroded fuel are opened in the basin. The first question to be answered by the first gas/liquid sampling campaign thus is: "which canisters are most likely to yield the proper fuel and sludge for hot cell examinations and to introduce only limited radionuclide contaminants to the $K$ West Basin during the initial characterization stages i.e., during the canister opening process?" Synergisms in this regard are summarized in Figure 1. 
Table 1. Interfaces between Fuel, Sludge and Gas/Liquid Sampling and Data Needs of the SNF Project

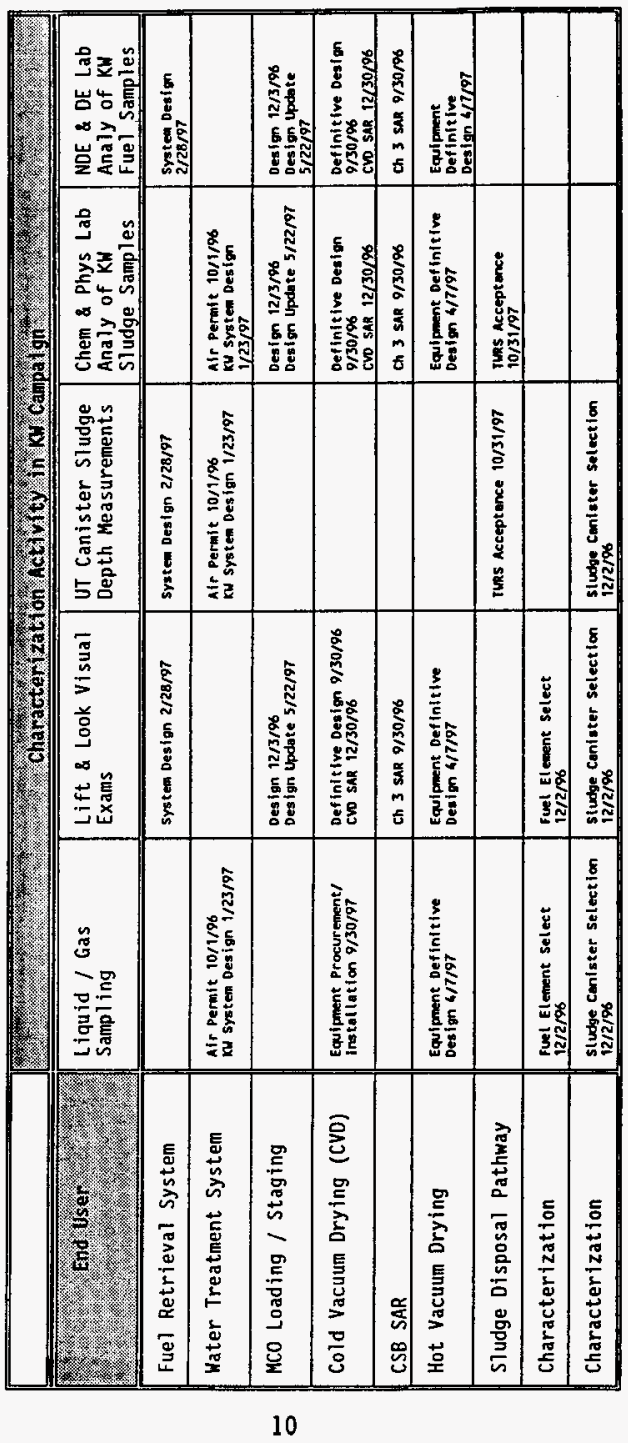


Figure 1. Flowchart of Interaction Between Gas/Liquid Sampling Described in this DQO Document and the Fuel/Sludge Tasks Described in the DQO Documents (Lawrence 1996; Makenas 1996a).

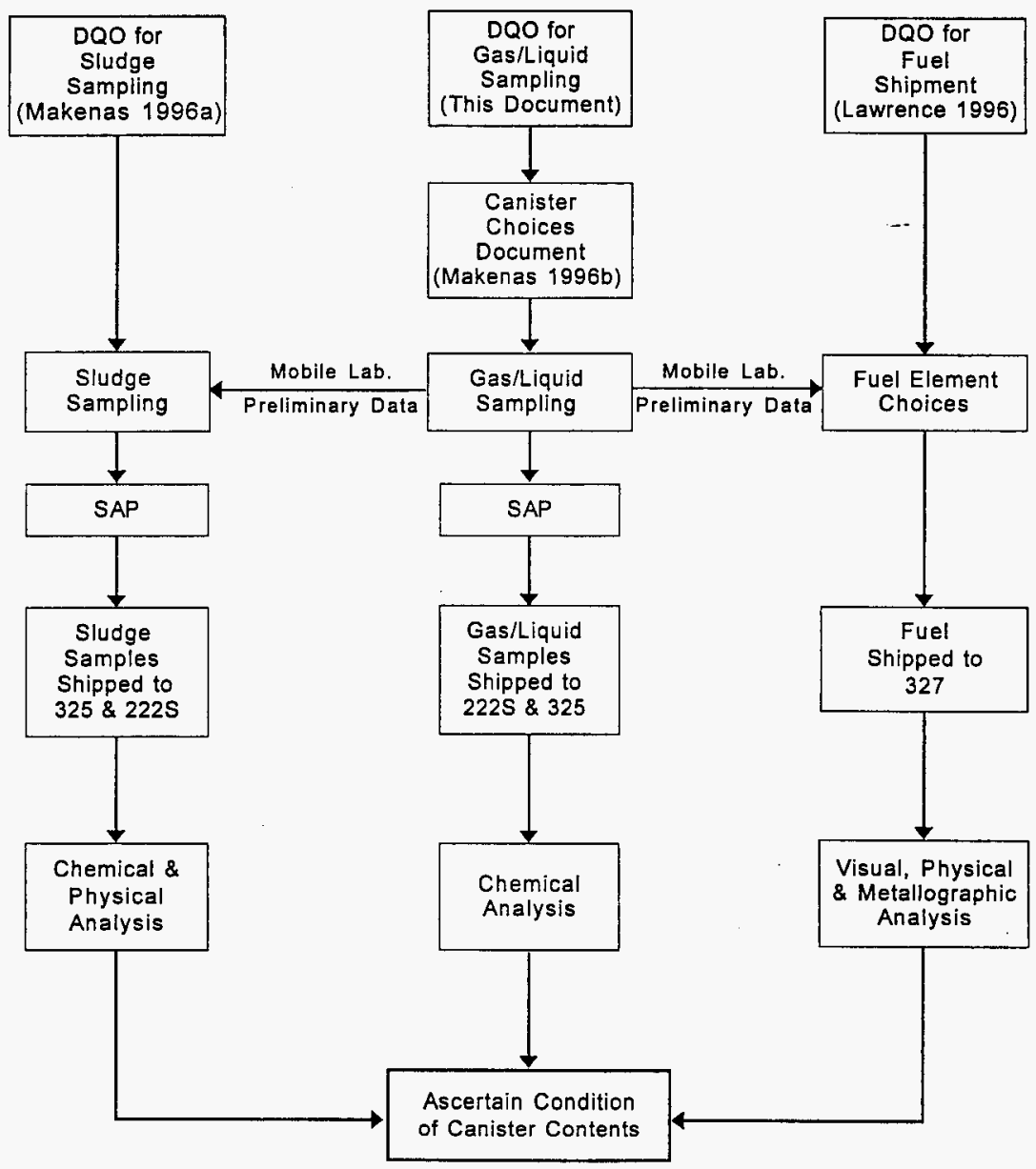


WHC-SD-SNF-DQO-006, Rev. 0

The fuel located in this manner will be used in such examinations as wholeelement drying tests and the sludge will be subject to various physical and chemical property tests to be described by future $0 Q 0$ documents.

A11 of the $K$ West canisters will eventually need to be opened as part of the process which will move $K$ Bas in fuel to interim dry storage. Just like the characterization process discussed above, such wholesale opening will result in release of radionuclides into the basin. The proposed gas and liquid sampling will provide an early estimate of these releases to be used by personnel planning the techniques, frequency, permitting and dose mitigation strategies associated with fuel retrieval, and repackaging for dry storage. The second question addressed by the current campaign thus is: "What are the concentrations of radionuclides in a limited number of $K$ West canisters and can these be extrapolated to an estimate of total radionuclide release for the basin during processing of all canisters?"

When the fuel is moved to dry storage some sludge (including corroded fuel particulates) will accompany the fuel during the processing and transport steps and will be dried with the fuel. An estimate of total sludge inventory is desired in order to bound the difficulty of drying both fuel and sludge in intimate contact with one another. The amount of sludge may not be easily ascertained during visual inspection since sludge can hide in the cracks and voids of a corroded fuel element. It has been proposed that an estimate of hidden sludge in a canister can be made by subtracting a measured amount of sludge in the canister from the total amount of fuel corrosion product. The total amount of corrosion product can be estimated from the concentration of specific fission product radionuclides in the water if the chosen radionuclides are soluble and if the fuel burnup can be determined from radionuclide isotopic ratios. Sludge volume measurements would be made as part of a subsequent campaign involving canister opening. Thus the final question to be answered is "what is the inventory of hidden sludge in elements in a canister as determined from the released radionuclides and measured siudge volumes?"

The method of sampling canisters must conform to certain constraints. These include the necessity for the sampling to be done safely (from a public and worker point of view), the necessity for ALARA considerations, the recognition that resources of operations personnel are 1 imited, and the necessity for not appreciably worsening the basin contamination situation during sampling. A sufficient number of canisters must be sampled to meet the objectives discussed above. Target analytes must include those which will aid in the interpretation of subsequently acquired fuel and sludge data. 
WHC-SD-SNF-DQ0-006, Rev. 0

This page intentionally left blank. 
WHC-SD-SNF-DQ0-006, Rev. 0

\subsection{IDENTIFY THE DECISIONS OR DECISION PATHS}

Sampling of gas and water from closed $k$ West canisters will endeavor to answer the following questions or contribute to specific decision pathways related to characterization issues/decisions.

a. Fuel Shipping for Examination: Several issues are connected with the near term shipping of fuel to the hot cells. Is the contamination level inside of closed canisters sufficient to cause unacceptable levels of radioactive species in the basin pool or adjacent air space when a limited number of specific canisters are opened for extraction of sludge and shipping of fuel to Hanford hot cells? Will additional ion-exchange capacity be needed to mitigate the effects of the canister opening? A cesium-137 content in one barrel over $150 \mathrm{Ci}$ is expected to preclude or at least delay opening of that barrel since the capacity of one fresh Ion Exchange Module (IXM) would be exceeded. The cesium-137 content of a barrel which exceeds the excess capacity of a current IXM would mandate the replacement of the IXM prior to opening of the canister barrel. Experience from the previous campaign of fuel retrieval in $K$ West Basin (Makenas 1995b) indicates that one outer fuel element with sufficient corrosion to split cladding will release about $0.5 \mathrm{Ci}$ of cesium-137 into a barrel. Prime target canisters for opening during the current campaign would be expected to contain at least this much cesium-137. Thus, liquid and gas sampling are expected to take place in conjunction with efforts to ship fuel to hot cell for examinations which are covered under a separate DQO document (Lawrence 1996). Sampling to address these issues will be for quantification of radioactive contaminants in the liquid (primarily) and gas (secondarily) of particular canisters with a firm decision made on which canisters will be opened to yield the best fuel specimens for hot cell examination.

b. Interim Storage and Associated Processing: How much sludge must be dealt with in the eventual shipping and drying of all of the $k$ West Basin fuel when it is removed from the basin. Another way to phrase this question is "how much corrosion of damaged fuel has taken place in the closed canisters"? since it is the corrosive process which gives rise to the release of fission products, the production of some hydrogen and the production of a nonadherent hydrated oxide i.e., sludge. Liquid samples primarily will contribute understanding here although release of hydrogen and krypton will also yield corroborative information at low corrosion levels. The cesium-137 content dissolved in the liquid will be used to estimate the total sludge produced (at a given burnup). The sludge trapped in damage elements will be estimated by subtracting the amount of sludge determined (by depth and density measurements) when canisters are opened from the total sludge produced. If the amounts of sludge determined by this methodology exceed the design assumptions for 
MCOS (currently $277 \mathrm{~g} / \mathrm{MCO}$ ) desludging of elements, prior to loading in an $\mathrm{MCO}$, will need to be aggressive and credit for desludging will be incorporated into the design justification. Measured amounts of sludge less than the assumed design values will simply lend credence to the current design.*

c. Fuel Handling and Air Permits: When the bulk of the $K$ West fuel is repackaged for interim storage the gas and liquid contents of the canisters will be disgorged into the pool water. It is expected that a water treatment system will be in place at that time to remove radionuclides and particulates from the local area where fuel handling is occurring. An air permit will also be prepared which will bound the emissions into the air which might occur during the fuel process. Estimates of radionuclide concentrations in the canisters water and gas will be necessary both to plan the management of the water treatment system and to prepare or supplement the air permit application. Specifically the amount of radionuclides in the water (such as cesium-137 and plutonium) along with similar concentration values for canister sludge, will determine the lifetime of an IXM and thus the number of IXMs to be brought and disposed after use. If this number of IXMs is unacceptable from operational interference and handling dose points of view, (greater than approximately 18 IXMs for processing the entire $K$ West fuel inventory) then filtration of water and sludge may necessarily prior to entry of the water stream into an IXM.

d. Inhibitors: Is the corrosion inhibitor (potassium nitrite added when the canisters were filled) effective and to what extent has it been consumed or diluted? Analysis here will be for the presence of the inhibitor or its conversion products in the liquid. These data are necessary to interpret differences in the quantity of corrosion between canisters. Fuel elements with similar initial damage should corrode less in the presence of higher inhibitor concentrations but this remains to be demonstrated. Inhibitor concentrations obtained will be compared directly to visual observations made during canister opening and during hot cell examinations.

*Although mentioned later in this report, it is worth noting here that uncertainties in the totality of cesium release during corrosion will affect the accuracy of this analysis as will any plating-out of cesium on surfaces other than sludge. 
WHC-SD-SNF-DQ0-006, Rev. 0

\subsection{THE DATA TO BE ACQUIRED AND TECHNIQUES TO BE UTILIZED}

Previous sampling experience has shown that the above questions can at least be partially addressed by obtaining small (approximately $20 \mathrm{ml}$ ) samples of gas and water from the sealed $K$ West canisters. One barrel of a Mark II canister is shown schematically in Figure 2. Samples can be taken through the two vent valves in the canister lid. The sampling apparatus will seal with the canister lid, open valves, extract a small sample of gas or water and reseal the vents. Such an apparatus has been designed and constructed. It is shown in Figure 3 and described in (Pitkoff 1994a, 1994b) with recent modifications given in (Trimble 1996c). This device uses two evacuated vials: one to draw gas through the off-center vent valve and one to draw liquid through the thin tube which is attached to the underside of the central valve. Experience has also shown (Makenas 1995b) that for best results canister barrels should be flooded (after gas sampling) with basin water (eliminating the $21 / 2$ in. gas space) prior to obtaining a water sample. The apparatus is designed to interface with either Mark I or Mark II canisters. Operation of the apparatus is specified in Reference (Master Work Plan 1995).

Particular laboratory procedures will be specified in the Sample Analysis Plan (SAP) (Harris 1996). The types of data to be acquired as part of the initial campaign are summarized in Table 2. The desired data include the concentration of several specific analytes, such as cesium or hydrogen, and include qualitative determinations such as whether a water sample is obtained when a gas sample is expected (indicating a leaking, flooded canister). Also listed in Table 2 are the rationale connecting each desired datum to the questions asked in Section 3.0 of this report. Concentrations of cesium, hydrogen, and fission gas will allude to corrosion rates since these are produced or released during the oxide forming process. Remaining nitrogen will indicate how much gas has been swept out through the gas trap. Hydrogen and oxygen will quantify radiolysis while the amount of argon will be a marker for contamination of sample with air.

It is recognized that, due to the multitude of processes occurring in a canister (such as water leakage and the sweep out, through the gas trap, of krypton and $\mathrm{N}_{2}$ by $\mathrm{H}_{2}$ generation), a true mass balance will probably not be obtainable and that different analytes (such as fission gas versus cesium) will more than likely give differing numbers for corrosion rates. This situation is further complicated by the fact that other relevant data, such as how much cesium is trapped in the sludge, will not be known until subsequent characterization campaigns (such as sludge sampling) have been completed. Extrapolation of the concentration numbers or gas to absolute quantities will. require assumptions about the size of the gas space versus the liquid level since the canister gas/liquid interface will not be directly observable. 
Figure 2. Schematic Drawing of $\mathrm{K}$ West Mark II Canister.

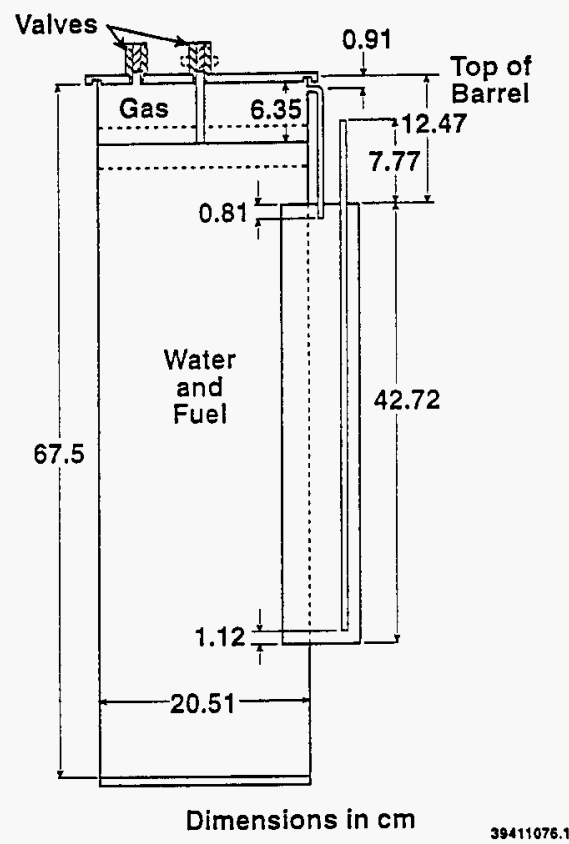


WHC-SD-SNF-DQ0-006, Rev. 0

Figure 3. Apparatus for Sampling Gas and Liquid from Sealed Canisters.

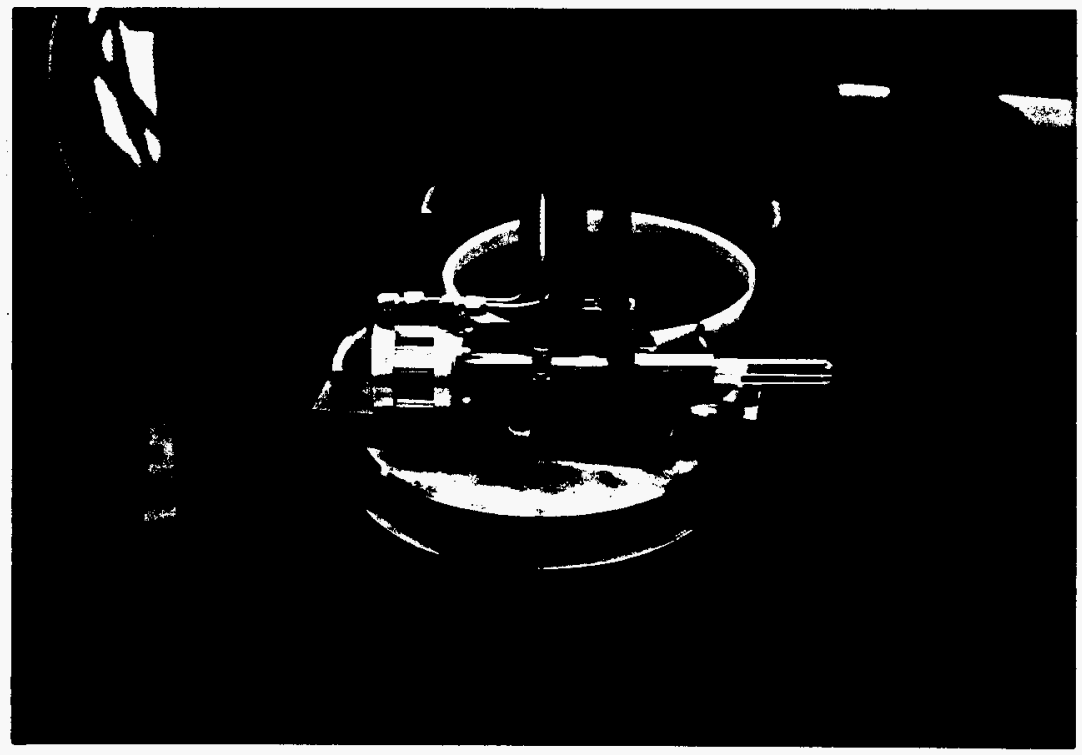


Table 2. List of Analytes for Canister Gas and Liquid Sampling.

\begin{tabular}{|c|c|c|c|c|}
\hline Element/Phenomenon & Gas/Liquid & $\begin{array}{l}\text { Rational } \\
\text { (from Section 3.0) }\end{array}$ & Notes/Cautions & $\begin{array}{c}\text { Responsible } \\
\text { Facility }\end{array}$ \\
\hline Cesium & Liquid & $\begin{array}{l}\text { Total corrosion } \\
(3 a, 3 b, 3 c)\end{array}$ & $\begin{array}{l}\text { Cesium plating out } \\
\text { or in sludge }\end{array}$ & $\begin{array}{l}\text { 222-S Laboratory } \\
\text { and MLT* }\end{array}$ \\
\hline Hydrogen & Gas & Corrosion (3a) & $\begin{array}{l}\text { Escape from trap; } \\
\text { radiolysis hydrogen }\end{array}$ & 325 Building \\
\hline $\begin{array}{l}\text { Atmospheric gases } \\
\text { (Ar:N:0) }\end{array}$ & Gas & $\begin{array}{l}\text { Equipment leakage or } \\
\text { sample contamination }\end{array}$ & & 325 Building \\
\hline Nitrogen & Gas & $\begin{array}{l}\text { Remaining covergas } \\
(3 a)\end{array}$ & Diluted with $\mathrm{H}$ & 325 Building \\
\hline $\begin{array}{l}\text { Nitrite and } \\
\text { potassium }\end{array}$ & Liquid & $\begin{array}{l}\text { Amount of inhibitor } \\
\text { added and remaining } \\
\text { in canister (3d) }\end{array}$ & $\begin{array}{l}500 \text { ppm specified } \\
\text { for addition during } \\
\text { encapsulation }\end{array}$ & 222-S Laboratory \\
\hline Nitrate & Liquid & $\begin{array}{l}\text { Inhibitor Rxn product } \\
\text { (3d) }\end{array}$ & $\begin{array}{l}\text { Corrosion and } \\
\text { radiolysis products } \\
\text { react with inhibitor }\end{array}$ & 222-S Laboratory \\
\hline $\begin{array}{l}\text { Fission gas } \\
\text { (krypton/xenon) }\end{array}$ & Gas & $\begin{array}{l}\text { Release from corroded } \\
\text { fuel; compare to } H \\
\text { results }(3 \mathrm{a}, 3 \mathrm{c})\end{array}$ & $\begin{array}{l}\text { Uncertainty in gas } \\
\text { release from oxide } \\
\text { and sludge }\end{array}$ & $\begin{array}{l}325 \text { Building and } \\
\text { MLT }\end{array}$ \\
\hline Hydrogen/oxygen & Gas & Radiolysis (3b) & $\begin{array}{l}\text { Other } \mathrm{H} \text { and } O \\
\text { sources i.e. } \\
\text { corrosion and air }\end{array}$ & 325 Building \\
\hline $\begin{array}{l}\text { Liquid obtained } \\
\text { when gas expected }\end{array}$ & Liquid/gas & $\begin{array}{l}\text { Identify leaking } \\
\text { canisters; compare to } \\
\text { gas trap measurements }\end{array}$ & & K Basin \\
\hline $\begin{array}{l}{ }^{90} \mathrm{Sr}, \mathrm{Pu}(239 / 240, \\
238) \text { U, tritium }\end{array}$ & Liquid & $\begin{array}{l}\text { Expected release when } \\
\text { canisters are opened } \\
(3 \mathrm{c})\end{array}$ & & 222-S Laboratory \\
\hline $\mathrm{pH}$ & Liquid & $\begin{array}{l}\text { General chemistry; } \\
\text { compare to basin } \\
\text { water and to sludge }\end{array}$ & & 222-S Laboratory \\
\hline $\begin{array}{l}\text { Total alpha and } \\
\text { beta/gamma }\end{array}$ & Liquid & $\begin{array}{l}\text { Integrated hazard of } \\
\text { canister opening } \\
(3 \mathrm{a}, 3 \mathrm{c})\end{array}$ & & $\begin{array}{l}222-S \text { Laboratory } \\
M L T \text { and KBRC** }\end{array}$ \\
\hline
\end{tabular}

NOTE: QC requirements (duplicates, spikes, etc.), precision, accuracy, procedure numbers, and practical quantification limits will be specified in the SAP (Harris, 1996)

$\star M L T=$ Mobile laboratory truck.

$\star \star K B R C=K$ Basin Radiological Control 


\subsection{DEFINE THE BOUNDARIES OF THE SECOND GAS LIQUID SAMPLING CAMPAIGN}

Current operational and schedular considerations are expected to limit this second campaign to 50 canisters (100 barrels). Gas and liquid sampling will be performed prior to sampling for fuel and sludge. The previous campaign sampled only non-leaking MK II SS canisters with evidence of gas generation and in some cases with known broken fuel. $K$ West canisters of the following types will be sampled during the second campaign.

- MK II SS Canisters: Priority will be given to those canisters with known broken fuel as indicated in the current fuel data base. The sampled population should include leaking canisters (as evidenced by broken locking bars and water-filled gas traps) and canisters with gas filled traps. The population of canisters with known broken fuel is small. However, experience with $K$ East Basin fuel and with previous $K$ West gas/liquid sampling would suggest that most canisters have at least some damaged fuel and the potential for hydrogen generation and cesium release. Sampled MK II canisters should span the available fuel burnup range $\left(4-13 \%{ }^{260} \mathrm{Pu}\right.$ in $\mathrm{Pu}$ and span the 7 years range of encapsulation dates.

- Chip Cans: Canister barrels with both gas-filled and water-filled gas traps should be represented. All chip cans are MK II design.

- Canisters with D Grade Material: This fuel was sorted in the $K$ East Basin during the segregation run and moved to $K$ West Basin via $N$ basin. Canister barrels with both gas-filled and water-filled gas traps should be represented. D Grade fuel which is known to be broken should be represented. A11 D Grade material is in MK II design canisters and $D$ Grade presents the opportunity to examine high burnup fuel as indicated by ${ }^{240} \mathrm{Pu}$ contents up to $15-17 \%$ of total Pu.

- MK I Canisters: Both MK IA and MK IV fuel types should be represented. A portion of the sampled canisters should contain known broken fue1. A span of burnups should be represented (as judged by key date of the fue 1 ). No records are known on which canisters are aluminum and which are SS. Therefore canisters from early and late encapsulation dates should be chosen for sampling on the assumption that only the earliest loadings used aluminum canisters. No records exist on which MK I canisters are leaking and which are still gas-filled.

Choices of MK II canisters to sample should be made to take advantage of the fact that, for a given canister, one barrel may be gas-filled and one may be water-filled, thus giving data from a single fuel key and a single encapsulation date for two different environments. A 1 ist of specific canisters to open will be specified via a separate document (Makenas 1996b). This latter document should present justification for the proportion of 50 canisters allotted to each canister category. Canister types discussed above are summarized in Table 3 . 
WHC-SD-SNF-DQ0-006, Rev. 0

Table 3. Candidate Canister Categories for Gas/Liquid Sampling in $K$ West Basin.

\begin{tabular}{|c|c|c|c|}
\hline $\begin{array}{l}\text { No. of Canisters to } \\
\text { Sample }\end{array}$ & $\begin{array}{l}\text { No. of } \\
\text { Barrels }\end{array}$ & Canister Type & Characteristics \\
\hline 15 & 30 & MK 2 & $\begin{array}{ll}\text { Known Broken Fuel } & \text { - Leaking Barrels or } \\
& \text { - Gas Filled Traps } \\
\text { Unknown Fuel } & \text { - Leaking Barrels or } \\
\text { Integrity } & \text { - Gas Filled Traps }\end{array}$ \\
\hline 5 & 10 & MK 2 & $\begin{array}{l}\text { Chip Cans with Mixed Gas and Water } \\
\text { Filled Traps }\end{array}$ \\
\hline 5 & 10 & MK 2 & $\begin{array}{l}\text { D - Grade Fuel with Mixed Gas and Water } \\
\text { Filled Traps }\end{array}$ \\
\hline 25 & 50 & MK I & $\begin{array}{l}\text { Known Broken Fuel, Including MK } 1 \mathrm{~A} \text { and } \\
\text { MK } 4 \text { Fuel Types } \\
\text { Unknown Fuel Integrity with Earl iest and } \\
\text { Latest Encapsulation Dates Available } \\
\text { Unknown Fuel Integrity with Earliest Key } \\
\text { Date }\end{array}$ \\
\hline $\begin{array}{c}\text { Total } \\
50\end{array}$ & 100 & & \\
\hline
\end{tabular}


It is expected that, like the previous data, gas samples taken during the current campaign will contain mostly hydrogen which will purge most other gases through the gas trap. Therefore, only a minority of canisters will be sampled for gas. All will contribute a liquid sample. Which canisters will be sampled for gas will be specified in (Makenas 1996b).

All liquid samples will be analyzed via mobile laboratory for cesium isotopes. Corrosion inhibitor concentrations should be determined for all canister barrels which will supply fuel or sludge and also from enough other barrels to establish whether adequate inhibitor was added initially and whether a correlation between corrosion (measured by cesium content) and inhibitor concentration exists. Analysis for inhibitor in known leaking barrels is, however, not required. Other radionuclide determinations such as for plutonium, should be performed on canister barrels where cesium-137 concentrations exceed $300 \mathrm{mCi} /$ barrel for the mobile laboratory initial estimates. The $\mathrm{pH}$ and total radiation measurements need be done on only a minority of samples. Mobile laboratory cesium concentrations should be confirmed by standard laboratory analysis in a minority of cases. Which samples will receive which laboratory wet-chemistry analyses will be specified in Letters of Instruction based on a SAP (Harris 1996) and those decisions will be based on the initial mobile laboratory data. 
WHC-SD-SNF-DQ0-006, Rev. 0

This page intentionally left blank. 


\subsection{DECISION LOGIC}

This section relates the needed decisions identified in Section 3.0 with the results obtained through gas and water sampling. A specific decision rule can be defined in Case $6 a$, i.e., for the choice of shipping candidates. For Cases $6 \mathrm{~b}$ through $6 \mathrm{~d}$ the goal is data gathering where only limited data currently exist and to provide mechanistic understanding to correlate with other data gathering activities.

a. Shipping: Section $3 a$ calls for a decision on which canisters to open based on the amount of contamination present in the canisters. If the cesium-137 content of a canister barrel is above $150 \mathrm{Ci}$ then the subject canister may not be chosen for the initial fuel and sludge shipping campaign due to limitations of the basin ion-exchange system (Mollarus 1995). Similarly, a lower limit of around 0.2 curies per barrel will be established to guarantee some non-negligible corrosion has occurred in the canister barrel. References (Lawrence 1996, Makenas 1996a) document the details of the decision logic associated with these choices. The canister choice document (Makenas 1996b) for shipping will identify responsible individuals and the proper point of decision.

b. Interim Storage: Section $3 b$ discusses the need for quantification of fuel corrosion as input to the Path Forward design efforts. It is very likely that by the time samples covered by this DQO document are acquired and analyzed that the Path Forward for basin fuel will have been essentially chosen using only currently available information. This chosen path has, of necessity, made certain assumptions about the amounts of existing corrosion product [including sludge (Gerber 1996)], liquid contaminants, potential corrosion processes (such as hydrogen generation), and radiolysis. The role of the data gathering during gas/liquid sampling will be a confirmatory one as to whether those design assumptions were correct.

c. Fuel Handling and Air Permits: It is currently estimated that removal of a11 of the fuel from the $K$ West Basin will necessitate the procurement, usage, and disposal of 9 IXMs. This is based on extrapolation of the average radionuclide concentrations from the previous gas/liquid sampling campaign. If the larger population of this second campaign demonstrates that radionuclide concentrations will be considerabiy higher than the extrapolation, then additional IXMs will be procured and in the extreme case (where operational interference and handling dose are unacceptable) additional removal capabilities will need to be designed and implemented. It should be noted that such decisions will be made with the benefit of additional data on canister sludge quantity and composition (the subject of another DQO document, Makenas 1996a). 
Data gathered by the current sampling campaign may not arrive in time to affect the initial draft of the air permit application (to DOE for review in 0ctober 1996). However data will be available as confirmatory/supplementary information to the initial permit bounding estimates.

d. Inhibitors: Inhibitor concentration data is being taken to correlate with the visible condition of the fuel to be ascertained in later sampling campaigns as well as with cesium concentrations in the liquid. It may provide the mechanistic explanation for varying degrees of corrosion if such variations are found and it may provide insight into the reliability of the original inhibitor injection (purging) process. 


\subsection{DECISION ERRORS}

The consequences of failure to obtain the data or of obtaining an incorrect result are qualitative at this time. They are:

a. The Path Forward MCO may be over or under designed for handling generated gas if the amount of corrosion and radiolysis are not correctly estimated. This could lead to unnecessary expenditure of resources due to reconsideration of design decisions such as canister venting or sealing. Gas/liquid sampling is one component of the data that will be evaluated to understand the potential for and extent of formation of water bearing sludges in an MCO.

b. Radionuclide concentrations in the pool water due to opening canisters (for hot cell shipping or for other processing associated with Path Forward) may be unexpectedly high during opening or handling processes if the mobile fission products are underestimated. Water cleanup systems could be unexpectedly overloaded during fuel retrieval for characterization.IXM procurements and IXM changeout time allotments for water cleanup systems associated with extensive fuel shipments to interim storage could differ significantly from the current planning baseline. 
WHC-SD-SNF-DQ0-006, Rev. 0

This page intentionally left blank. 


\subsection{DECISION OPTIMIZATION}

The 50 canister population to be sampled must be apportioned among a number of different canister types, damage severities, and fuel types. This probably does not result in a large number of canisters in each subpopulation. If a large variation in properties is found within a particular subpopulation and if that subpopulation represents a large and significant fraction of the basin canisters, additional sampling from that type of canister may be necessary to establish statistical rigor.

The decisions and data analysis activities described in this DQO will be made in concert with future fuel and sludge retrieval campaigns. As such, the gas/liquid, canister sludge, and fuel sampling activities should be considered complementary. 
WHC-SD-SNF-DQD-006, Rev. 0

This page intentionally left blank. 
WHC-SD-SNF-DQO-006, Rev. 0

\subsection{REFERENCES}

Emory, B. B., 1994, "K West Fuel Canister Candidates for Sampling Based on 1982 Results," Westinghouse Hanford Company Internal Memo, 8E140-94-129, October 24, 1994.

Fulton, J. C., 1994, Hanford Spent Nuclear Fuel Project Recommended Path Forward, Vol. 1, WHC-EP-0830, Rev. 0, Westinghouse Hanford Company, Rich1 and, Washington.

Gerber, E. W., 1996, Letter to B. S. Carlisle, "Bounding Multicanister Overpack Particulate Inventory," 2C000-96032.

Harris, R. A., 1995, Sampling and Analysis Plan For Canister Liquid and Gas at 105-K West Fue7 Storage Basin, WHC-SD-SNF-PLN-004, Rev. 0, Westinghouse Hanford Company, Richland, Washington.

Harris, R. A., 1996, Sampling and Analysis Plan For Canister Liquid and Gas at $105-K$ West Fuel Storage Basin for the Second Campaign $K$ West, to be Published WHC-SD-SNF-PLN-004, Rev. 1, Westinghouse Hanford Company, Rich1 and, Washington.

Lawrence, L. A., 1994, Spent Nuclear Fuel Project Characterization Data Quality Objectives Strategy, WHC-EP-0795, Westinghouse Hanford Company, Richland, Washington.

Lawrence, L. A., 1996, Data Quality Objectives for the Second Campaign $K$ West Fuel Element Examinations, to be Published, Westinghouse Hanford Company, Richland, Washington.

Makenas, B. J., 1995, Observations During the First $K$ West Fuel Shipping Campaign, WHC-SD-SNF-ER-010, Rev. 0, Westinghouse Hanford Company, Richland, Washington.

Makenas, B. J., 1996a, Data Quality Objectives for Sludge Sampling in $K$ West Basin, WHC-SD-SNF-DQ0-010, to be Published, Westinghouse Hanford Company, Richland, Washington.

Makenas, B. J., 1996b, Choices of Canisters and Elements for the Second Fuel Shipment and Gas/Liquid Sampling from $K$ West Basin, WHC-SD-SNF-SM-005, to be Published, Westinghouse Hanford Company, Richland, Washington.

Master Work Plan, 1995, $K$ East and $K$ West Basin Fuel Characterization, MWP-95005, Westinghouse Hanford Company, Richland, Washington.

Mollarus, F. J., 1995, An Assessment for $K$ Basin Radionuclide Activity While opening SNF Canisters, WHC-SD-SNF-SE-006, Rev. 0.

Pitkoff, C. C., 1994a, Gas and Liquid Samples for Closed Canisters in $K$ West Basin--Functional Design Criteria, WHC-SD-SNF-FDC-001, Rev. 0 , Westinghouse Hanford Company, Richland, Washington. 


\subsection{REFERENCES (Continued)}

Pitkoff, C. C., 1994b, Gas and Liquid Sampling for Closed Canisters in $K$ West Basin--Test Plan, WHC-SD-SNF-TP-008, Rev. 0, Westinghouse Hanford Company, Richland, Washington.

Trimble, D. J., 1996a, Data Ana7ysis, K West Basin Canister Liquid and GaS Samples, Gamma Energy Analysis and Mass Spectrometry Data, WHC-SD-SNF-ANAL-007, Rev. 0, Westinghouse Hanford Company, Richland, Washington.

Trimble, D. J., 1996b, Data Analysis of Gas and Liquid from $K$ West Canisters; 1995 Samples," WHC-SD-SNF-ANAL-008, Rev. 0, Westinghouse Hanford Company, Richland, Washington.

Trimble, D. J., 1996c, Test Plan for Sealed Canister Gas/Liquid Sampling/Equipment, WHC-SD-SNF-TP-030, Rev. 0, Westinghouse Hanford Company, Richland, Washington.

Weber, J. W., 1994, Review of Consequences of Uranium Hydride Formation in $N$ Reactor Fuel Elements Stored in $K$ Basins, WHC-SD-SNF-SARR-001, Rev. 0 , Westinghouse Hanford Company, Richland, Washington. 
WHC-SD-SNF-DQ0-006, Rev. 0

A P P E N D I X A

SUMMARY OF PREVIOUS DATA FROM GAS AND LIQUID SAMPLING OF $K$ WEST CANISTERS

--Excerpted from References Trimble 1996a and 1996b-- 
WHC-SD-SNF-DQO-006, ReV. 0

This page intentionally left blank. 
The following are conclusions from the analysis of water and gas sample data from MK II canisters storing MK IV fuel in the $K$ West Basin. The grade and age of the fuel in the sampled canisters were $11.6 \%$ plutonium-240 and 12.6 years, respectively. Canisters having relatively low levels of water in the gas traps were chosen for the sampling. Low gas-trap water level indicates good lid seals and significant hydrogen generation possibly due to uranium corrosion.

- Cesium-137 in the canister water averaged $143 \mathrm{mCi} /$ barrel and was the result of the corrosion of exposed fuel (uranium). An interim analysis of the data indicated that most cesium in the corroded fuel was released and dissolved in the water. Therefore, it is expected that the mass of fuel corrosion in a barrel can be estimated from the cesium-137 in the water.

- Strontium-90 in the canister water averaged $10 \mathrm{mCi} /$ barrel. Significant amounts of the strontium from corroded fuel were not found in the canister water.

- Tritium in the canister water averaged $0.26 \mathrm{mCi} /$ barre1. About one-third of the tritium that was released by fuel corrosion was dissolved in the water. Although not evaluated, it was assumed that the remaining tritium was released to the canister gas.

- Uranium in the canister water averaged $23 \mathrm{mg} /$ barrel.

- Plutonium and americium isotopes in the canister water were in all cases less than $50 \mu \mathrm{Ci}$ /barrel. Plutonium-238 and plutonium-239/240 were generally less than $11 \mu \mathrm{C} /$ barrel. A better measure of these isotopes could be made from larger samples than those acquired in the first $K$ West sampling campaign.

- Corrosion inhibitor may not have been added to the canister water as specified. It was found in amounts less than $17 \%$ of that expected. Assuming that it was added during the encapsulation process as specified, it may have reacted forming products not investigated or it may have become insoluble.

- The $\mathrm{pH}$ of the water of flooded canisters was on the basic side ranging from 7.2 to 9.3 and averaged 7.9 .

- Canister gas contains significant amounts of radionuclides caused by the release of the gas nuclides by fuel corrosion. Measurements for krypton-85 averaged $3.1 \mathrm{mCi} /$ barrel and did not exceed $4.7 \mathrm{mCi} /$ barrel.

- An overall average for krypton-85 in canisters is $6.5 \mathrm{mCi} /$ barrel ( $11 \mathrm{mCi} / \mathrm{canister}$ ) or less, and in most cases, for the total canister population it will probably not exceed $9 \mathrm{mCi} /$ barrel

(18 $\mathrm{mCi} /$ canister). 
- Tritium in the gas could be as high as $0.47 \mathrm{mCi} /$ barrel but will probably not exceed $0.31 \mathrm{mC} i /$ barrel. It is expected for the total canister population to average about $0.21 \mathrm{mCi} /$ barrel.

- Hydrogen is the primary constituent of the canister gas, averaging over $80 \%$ of the gas. It is primarily the product of fuel corrosion although some hydrogen gas may have resulted from radiolysis (radiolytic decomposition) of the canister water.

- Some canisters contain significant oxygen in the gas possibly resulting from radiolysis of the water. 
WHC-SD-SNF-DQ0-006, Rev, 0

A P PENDIX B

LIST OF STAKEHOLDERS 
WHC-SD-SNF-DQ0-006, Rev. 0

This page intentionally left blank. 
List of Stakeholders for Gas/Liquid Sampling

\begin{tabular}{|l|l|}
\hline \hline Path Forward & $\begin{array}{l}\text { A. L. Pajunen, L. H. Goldman, } \\
\text { A. T. Kee, R. G. Cowan, C. R. Miska }\end{array}$ \\
\hline K Basin Operations & C. T. Miller \\
\hline Fuel Handl ing and Water Treatment & $\begin{array}{l}\text { W. C. Mills, D. L. Sherrell, } \\
\text { R. H. Meichle, T. R. Pauly }\end{array}$ \\
\hline Air Permits & R. G. Gant, G. S. Hunacek \\
\hline QA & D. W. Smith \\
\hline Mobile Laboratory & E. F. Riedel \\
\hline 222-S Laboratory & G. L. Miller \\
\hline 325 Building Laboratory & M. W. Goheen \\
\hline Equipment Design & A. E. Bridges \\
\hline Operations Interface & J. J. Jernberg \\
\hline Equipment \& Laboratory Interface & D. J. Trimble \\
\hline DOE/RL & J. Shuen \\
\hline Characterization Management & R. P. Omberg* \\
\hline Sample Analysis Plan & R. A. Harris \\
\hline Integration with sludge sampling & R. B. Baker \\
\hline Integration with fuel sampling & L. A. Lawrence/S. M. Marschman \\
\hline
\end{tabular}

*key decision maker. 


\begin{tabular}{|c|c|c|c|c|c|}
\hline \multicolumn{6}{|c|}{ DISTRIBUTION SHEET } \\
\hline To & \multirow{2}{*}{\multicolumn{3}{|c|}{$\begin{array}{l}\text { From } \\
\text { Nuclear Fuel Evaluations 8M710 }\end{array}$}} & \multicolumn{2}{|c|}{ Page 2 of 2} \\
\hline Distribution & & & & \multicolumn{2}{|c|}{ Date $7 / 16 / 96$} \\
\hline \multicolumn{4}{|l|}{ Project Title/Work Order } & \multicolumn{2}{|c|}{ EDT No. 615490} \\
\hline Spent Nuclear Fuel Project & & & & \multicolumn{2}{|c|}{ ECN No. } \\
\hline Name & MSIN & $\begin{array}{c}\text { Text } \\
\text { With All } \\
\text { Attach. }\end{array}$ & Text Only & $\begin{array}{l}\text { Attach./ } \\
\text { Appendix } \\
\text { Only }\end{array}$ & $\begin{array}{l}\text { EDT/ECN } \\
\text { Only }\end{array}$ \\
\hline $\begin{array}{l}\text { Westinghouse Hanford Company } \\
\text { R. B. Baker } \\
\text { D. W. Bergmann } \\
\text { A. E. Bridges } \\
\text { L. D. Bruggeman } \\
\text { B. S. Carlisle } \\
\text { S. A. Chastain } \\
\text { R. G. Cowan } \\
\text { J. C. Fulton } \\
\text { J. R. Frederickson } \\
\text { R. G. Gant } \\
\text { E. W. Gerber } \\
\text { L. H. Goldmann } \\
\text { J. C. Hamrick } \\
\text { R. A. Harris } \\
\text { S. L. Hecht } \\
\text { G. S. Hunacek } \\
\text { A. T. Kee } \\
\text { L. A. Lawrence } \\
\text { B. J. Makenas (5) } \\
\text { R. L. McCormack } \\
\text { C. T. Miller } \\
\text { G. L. Miller } \\
\text { W. C. Mills } \\
\text { C. R. Miska } \\
\text { R. P. Omberg } \\
\text { A. L. Pajunen } \\
\text { T. R. Pauly } \\
\text { J. Perez-Carter } \\
\text { C. C. Pitkoff } \\
\text { A. L. Pitner } \\
\text { E. F. Riedel } \\
\text { J. P. Schmidt } \\
\text { D. W. Siddoway } \\
\text { D. L. Sherrell } \\
\text { D. W. Smith } \\
\text { J. A. Swenson } \\
\text { D. J. Trimble (5) } \\
\text { J. W. Weber } \\
\text { M. J. Wiemers } \\
\text { SNF Project Files } \\
\text { Central Files ( }+ \text { oriz) } \\
\text { Document Processing Center }\end{array}$ & 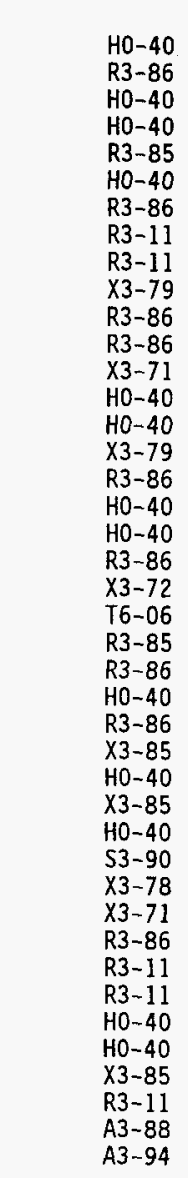 & $\begin{array}{l}x \\
x \\
x \\
x \\
x \\
x \\
x \\
x \\
x \\
x \\
x \\
x \\
x \\
x \\
x \\
x \\
x \\
x \\
x \\
x \\
x \\
x \\
x \\
x \\
x \\
x \\
x \\
x \\
x \\
x \\
x \\
x \\
x \\
x \\
x \\
x \\
x \\
x \\
x \\
x \\
x \\
x \\
x\end{array}$ & & & \\
\hline
\end{tabular}




\begin{tabular}{|c|c|c|c|c|c|c|}
\hline \multicolumn{7}{|c|}{ DISTRIBUTION SHEET } \\
\hline To & \multirow{2}{*}{\multicolumn{4}{|c|}{$\begin{array}{l}\text { From } \\
\text { Nuclear Fuel Evatuations } 8 M 710\end{array}$}} & \multicolumn{2}{|l|}{ Page 1 of 2} \\
\hline Distribution & & & & & \multicolumn{2}{|c|}{ Date $7 / 16 / 96$} \\
\hline \multirow{2}{*}{\multicolumn{5}{|c|}{$\begin{array}{l}\text { Project Title/Work Order } \\
\text { Spent Nuclear Fuel Project }\end{array}$}} & \multirow{2}{*}{\multicolumn{2}{|c|}{$\begin{array}{l}\text { EDT No. } 615490 \\
\text { ECN No. }\end{array}$}} \\
\hline & & & & & & \\
\hline Name & & MSIN & $\begin{array}{l}\text { Text } \\
\text { With All } \\
\text { Attach. }\end{array}$ & Text Only & $\begin{array}{c}\text { Attach./ } \\
\text { Appendix } \\
\text { Only }\end{array}$ & $\begin{array}{l}\text { EDT/ECN } \\
\text { Only }\end{array}$ \\
\hline $\begin{array}{l}\text { U.S. Department of Energy. } \\
\frac{\text { Richland Field Office }}{\mathrm{J} \text {. Shuen }}\end{array}$ & & $S 7-41$. & $x$ & & & \\
\hline $\begin{array}{l}\text { Washington State Department of } \\
\text { P.0. Box } 47600 \\
\text { 01ympia, Washington } 98504-7600\end{array}$ & ology & & & & & \\
\hline D. Silver & & & $x$ & & & \\
\hline $\begin{array}{l}\text { Washington State Department of } \\
\text { Airdustrial Park } \\
\text { Building 5, Mail Stop LE-13 } \\
\text { Olympia, Washington } 98504-0095\end{array}$ & alth & & & & & \\
\hline A. W. Conklin & & & $x$ & & & \\
\hline $\begin{array}{l}\text { Mac Technical Services Company } \\
\text { G. Baston } \\
\text { R. P. Denise } \\
\text { J. A. Sheriff }\end{array}$ & & $\begin{array}{l}\text { R3-82 } \\
\text { R3-82 } \\
\text { R3-82 }\end{array}$ & $\begin{array}{l}x \\
X \\
X\end{array}$ & & & \\
\hline $\begin{array}{l}\text { Pacific Northwest Laboratory } \\
\text { J. Abrefah } \\
\text { M. W. Goheen } \\
\text { S. C. Marschman } \\
\text { T. A. Thornton }\end{array}$ & & $\begin{array}{l}P 7-34 \\
P 7-22 \\
P 7-34 \\
P 7-34\end{array}$ & $\begin{array}{l}x \\
x \\
x \\
x\end{array}$ & & & \\
\hline
\end{tabular}

